\title{
Uusia mansikkalajikkeita Pohjois-Suomeen
}

\author{
Kati Hoppula $^{1)}$, Kalle Hoppula ${ }^{1)}$, Tarja Hietaranta ${ }^{2)}$, Risto Tahvonen ${ }^{2)}$ ja Marja Uusitalo ${ }^{3)}$ \\ ${ }^{1)}$ MTT Sotkamo, Kipinäntie 16, 88600 Sotkamo, etunimi.sukunimi@mtt.fi \\ ${ }^{2)}$ MTT Piikkiö, Toivonlinnantie 518, 21500 Piikkiö, etunimi.sukunimi@mtt.fi \\ ${ }^{3)}$ MTT Rovaniemi, Eteläranta 55, 96300 Rovaniemi, etunimi.sukunimi@mtt.fi
}

\section{Tiivistelmä}

Viime vuosina markkinoille on tullut uusia kotimaisia mansikkalajikkeita, Suvetar, Valotar ja Kaunotar sekä Kulkuri-koejaloste. Uudet lajikkeet ovat nyt ensimmäisen kerran lajikekokeissa MTT:n pohjoisilla tutkimusasemilla Sotkamossa ja Rovaniemellä. Lisäksi lajikekokeissa oli mukana ennestään tunnetut lajikkeet Polka, Honeoye, Senga Sengana, Jonsok, Bounty ja Korona. Sotkamossa ja Rovaniemellä tehtyjen mansikan lajikekokeiden tavoitteena oli löytää uusia satoisia ja talvenkestäviä lajikkeita Pohjois-Suomeen vakiintuneiden lajikkeiden lisäksi. Kokeet olivat osa EU:n Maaseuturahaston rahoittamaa ja MTT Sotkamon tutkimusaseman koordinoimaa Marjanviljelystä vahva elinkeino Pohjois-Suomeen -hanketta. Tässä käsitellään lajikekokeiden ensimmäisen satovuoden, 2009, tulokset.

Sotkamossa satoisimmiksi osoittautuivat lajikkeet Polka, Honeoye, Korona ja Bounty. Rovaniemellä selvästi parasta lajiketta ei kokeissa noussut esiin, mutta kokonaissadoltaan suurimmiksi ylsivät vanhat lajikkeet Senga Sengana, Bounty ja Polka. Uusimpien lajikkeiden Suvetar ja Valotar satomäärät riittivät Sotkamossa kannattavaan viljelyyn, vaikka ne eivät yltäneetkään parhaimpien lajikkeiden satotasolle. Rovaniemellä Suvetar ja Valotar tuottivat alle paikkakunnan keskimääräisen satotason. Lajike Kaunotar antoi keskimääräistä heikomman sadon molemmilla paikkakunnilla. Lajike Kulkuri antoi koko lajikekokeen heikoimman sadon molemmilla paikkakunnilla.

Harmaahometta esiintyi huomattavasti enemmän Sotkamossa kuin Rovaniemellä. Senga Sengana, Polka ja Korona osoittautuivat molemmilla paikkakunnilla joko erittäin aroiksi tai keskimääräistä aremmiksi harmaahomeelle. Uusista lajikkeista Suvetar oli Sotkamossa erittäin herkkä harmaahomeelle, mutta Rovaniemellä se yllättäen sieti hometta keskimääräistä paremmin. Lajikkeet Valotar, Bounty, Honeoye ja Kaunotar olivat keskimääräistä parempia homeenkestävyydeltään molemmilla paikkakunnilla. Homeenkestävyydeltään parhaimmaksi osoittautui lajike Kulkuri.

Yhden vuoden tulosten pohjalta uusista lajikkeista lupaavimmaksi satotasoltaan, homeenkestävyydeltään ja marjakooltaan osoittautui lajike Valotar. Lajike Kulkuri olisi myös kiinnostava erittäin hyvän homeenkestävyytensä ja ison marjakokonsa puolesta, mutta satotasot ovat aivan liian heikot tuottavaan viljelyyn. Vanhemmista lajikkeista Bounty osoittautui keskisatoiseksi, homeenkestäväksi ja kokeilemisen arvoiseksi, vaikka marjakoko jäikin hieman keskimääräistä pienemmäksi. Lajikekokeen jatko näyttää, pystyvätkö lajikkeet Valotar ja Bounty sopeutumaan pohjoisen oloihin pidemmällä aikavälillä ja tuottamaan riittävästi hyvänlaatuista satoa.

Asiasanat: Mansikat, puutarhamansikka, Fragaria x ananassa, lajikkeet 


\section{Johdanto}

Viime vuosina markkinoille on tullut uusia kotimaisia mansikkalajikkeita, Suvetar, Valotar ja Kaunotar sekä Kulkuri-koejaloste. Uudet lajikkeet ovat nyt ensimmäisen kerran lajikekokeissa MTT:n pohjoisilla tutkimusasemilla Sotkamossa ja Rovaniemellä. Pohjoisessa tällä hetkellä lajikkeet Polka ja Honeoye ovat vakiinnuttaneet paikkansa viljelyssä. Lajikkeet Bounty ja Korona ovat tuttuja etelän viljelijöille, mutta tuntemattomampia pohjoisen alueilla. Vanhoista lajikkeista Jonsok ja Senga Sengana ovat tunnettuja ja aikanaan viljeltyjä valtalajikkeita, mutta vähenevässä määrin enää tuotannossa.

Sotkamossa ja Rovaniemellä tehtyjen mansikan lajikekokeiden tavoitteena oli löytää uusia satoisia ja talvenkestäviä lajikkeita Pohjois-Suomeen vakiintuneiden lajikkeiden lisäksi. Kokeet olivat osa EU:n Maaseuturahaston rahoittamaa ja MTT Sotkamon tutkimusaseman koordinoimaa Marjanviljelystä vahva elinkeino Pohjois-Suomeen -hanketta. Tässä esitellään vuonna 2008 perustettujen mansikan lajikekokeiden ensimmäisen satovuoden, 2009, tulokset.

Lajikekokeiden uusista lajikkeista Suvetar ja Valotar ovat MTT:n kaksi uusinta mansikkalajiketta. Lajike Suvetar on peräisin lajikkeiden Emily ja Polka risteytyksestä ja lajikkeen Valotar risteytysvanhemmat ovat Senga Sengana ja Jewel (Hietaranta ja Parikka 2008). Molempien uutuuksien sato kypsyy satokauden keskivaiheilla samoihin aikoihin Polkan kanssa. Suvetar ja Valotar ovat härmänkestäviä ja kiinteämarjaisia lajikkeita, joiden harmaahomeen kestävyys on parempi kuin lajikkeella Polka. Lajikkeiden talvenkestävyydestä ei ole vielä varmoja tuloksia.

Kaunotar on lajikkeiden Hella ja Glima risteymä ja on uusista lajikkeista aikaisin (Hietaranta 2007). Sato kypsyy samoihin aikoihin Jonsok-lajikkeen kanssa. Kaunotar on marjan kiinteydeltään keskinkertainen, lajikkeen Bounty luokkaa. Kasvuston härmänkestävyys ei ole yhtä hyvä kuin muilla, mutta marjojen härmäoireista ei ole toistaiseksi havaintoja. Talvenkestävyys on ollut melko hyvä.

Kulkuri on lajikkeiden Hella ja Redgauntlet risteymä ja satokauden keskivaiheilla kypsyvä (Hietaranta 2007). Marjan pinta on pehmeähkö. Kasvustossa on havaittu jonkin verran härmäoireita, mutta ei marjoissa. Kulkuri on ollut talvenkestävyydeltään melko hyvä, samaa luokkaa Kaunotar-lajikkeen kanssa.

\section{Aineisto ja menetelmät}

Mansikan lajikekokeet perustettiin Maa- ja elintarviketalouden tutkimuskeskuksen tutkimusasemille Sotkamoon ja Rovaniemelle kesällä 2008. Molemmilla paikkakunnilla mansikan lajikekokeessa mukana olivat lajikkeet Senga Sengana, Jonsok, Polka, Honeoye, Korona, Bounty, Suvetar, Valotar, Kaunotar ja Kulkuri. Lajikekoe tehtiin neljän lohkon satunnaistettuna kokeena. Verranteina kokeissa olivat lajikkeet Polka ja Honeoye. Istutus tehtiin muovitettuun penkkiin, limittäin paririviin kuusi tainta rivimetrille. Jokaisessa ruudussa oli 15 tainta. Kastelu ja lannoitus annettiin tihkukasteluna. Kastelurajana pidettiin tensiometrilukemaa $-150 \mathrm{hPa}$. Ennen kokeen perustamista maan ravinnetasot nostettiin viljavuusanalyysin tasolle hyvä. Satovuonna 2009 lannoituksessa käytettiin Ferticare Combi 2 -kastelulannoitetta. Lannoitteen saanti kasvukauden aikana oli 4,4 g/taimi.

Sotkamossa ja Rovaniemellä mansikanlajikekokeiden kasvualustana oli hieno hieta. Lajikekokeen taimimateriaalina käytettiin kennotaimia (Puutarha Tahvoset), jotka istutettiin Sotkamossa 2008 heinäkuun alussa, paitsi lajike Kulkuri, joka istutettiin taimien saannin vuoksi vasta elokuun alussa. Rovaniemellä mansikan lajikekoe istutettiin heinäkuun lopulla 2008. Sotkamossa mansikkakasvustot ruiskutettiin kahdesti harmaahometta vastaan ja kerran härmää vastaan. Käytetyt torjunta-aineet olivat harmaahomeen torjuntaan Switch 62,5 (syprodiniili 375g/kg) ja Teldor (fenheksamidi 500 g/kg) sekä härmän torjuntaan Topas 100EC (penkonatsoli 100 g/l). Rovaniemellä torjunta-aineita ei käytetty.

Sato kerättiin Sotkamossa 7.7.-26.8.2009 ja Rovaniemellä 8.7.-24.8.2009. Sadosta lajiteltiin erikseen homeiset ja härmäiset marjat. Marjojen massa ja lukumäärä punnittiin laatuluokittain.

\section{Tulokset ja tulosten tarkastelu}

Parhaimman keskimääräisen sadon tainta kohden antoi Sotkamossa lajike Polka (Taulukko 1). Lajike Honeoye oli myös erittäin satoisa ja satotasoltaan lähes Polka -lajikkeen luokkaa. Hyvään satoon ylsivät myös lajikkeet Korona, Bounty, Suvetar ja Valotar. Kokonaissato jäi Rovaniemellä kaikilla lajikkeilla selvästi heikommaksi Sotkamoon verrattuna. Rovaniemellä parhaimman sadon antoi yllättäen lajike Senga Sengana (Taulukko 2). Lajikkeet Bounty ja Polka olivat Rovaniemellä kuitenkin kokonaissadoltaan samaa luokkaa lajikkeen Senga Sengana kanssa. Lajike Honeoye ei yltänyt satomäärissään kolmikon tasolle. 
Kokonaissadon suhteen uudet lajikkeet Suvetar ja Valotar olivat hieman keskimääräistä parempia Sotkamossa. Niiden sadot jäivät kuitenkin noin neljänneksen pienemmäksi kuin lajikkeella Polka. Rovaniemellä lajikkeiden Suvetar ja Valotar kokonaissadot jäivät noin puoleen lajikkeen Polka satotasosta. Kaunotar-lajikkeen satotaso jäi heikoksi molemmilla paikkakunnilla. Huonoin satotaso oli molemmilla paikkakunnilla lajikkeella Kulkuri.

Lajikekokeen suurimmat marjat olivat sekä Sotkamossa, että Rovaniemellä lajikkeella Honeoye. Lajikkeet Korona, Suvetar ja Kulkuri erottuivat myös keskimääräistä suuremmilla marjoillaan muista lajikkeista Sotkamossa. Lajikkeilla Honeoye, Suvetar ja Kulkuri oli suurimmat marjat myös Rovaniemellä, mutta Korona -lajike jäi siellä selvästi muita pienemmäksi. Valotar -lajikkeen marjakoko jäi hieman Polka-lajiketta pienemmäksi molemmilla paikkakunnilla. Uusista lajikkeista pienimmäksi osoittautui Kaunotar. Sotkamossa Kaunotar-lajikkeen marjat olivat koko kokeen pienimmät, mutta kuitenkin vain vähän pienemmät kuin Bounty -lajikkeen marjat. Rovaniemellä pienimmät marjat olivat lajikkeella Jonsok.

Homeisten marjojen määrä oli selvästi suurempi Sotkamossa kuin Rovaniemellä torjuntaruiskutuksista huolimatta. Molemmilla paikkakunnilla paras homeensietokyky oli lajikkeella Kulkuri ja huonoin lajikkeella Senga Sengana. Lajikkeet Valotar, Bounty ja Kaunotar erottuivat myös selvästi hometta kestävinä lajikkeina Sotkamossa. Kaunotar-lajikkeen homeenkesto oli hieman lajiketta Valotar heikompi, mutta ero ei ollut suuri. Rovaniemellä hyvällä homeensietokyvyllä erottui lajikkeiden Kulkuri, Valotar ja Kaunotar lisäksi yllättäen lajike Suvetar. Suvetar -lajikkeella oli kuitenkin Senga Sengana -lajikkeen jälkeen suurin homeisten marjojen määrä Sotkamossa. Lajikkeet Polka ja Korona olivat myös selvästi herkkiä harmaahomeelle molemmilla paikkakunnilla.

Sotkamossa ja Rovaniemellä sekä uusien että vanhojen lajikkeiden härmänkesto oli erittäin hyvä. Härmäisiä marjoja ei ilmennyt yhdelläkään lajikkeella.

Taulukko 1. Mansikan lajikekokeen satotulokset Sotkamossa 2009.

\begin{tabular}{llcll}
\hline Lajike & $\begin{array}{l}\text { Kokonaissato } \\
\text { g/taimi }\end{array}$ & $\begin{array}{l}\text { Marjakoko } \\
\text { g/marja }\end{array}$ & $\begin{array}{l}\text { Home } \\
\text { g/taimi }\end{array}$ & $\begin{array}{l}\text { Härmä } \\
\text { g/taimi }\end{array}$ \\
\hline Polka & 609 & 9,9 & 67,6 & 0,0 \\
Honeoye & 589 & 15,2 & 28,3 & 0,0 \\
Korona & 507 & 13,5 & 71,0 & 0,0 \\
Bounty & 454 & 8,5 & 25,9 & 0,0 \\
Suvetar & 445 & 12,5 & 89,9 & 0,0 \\
Valotar & 418 & 9,3 & 27,6 & 0,0 \\
Senga Seng. & 350 & 7,9 & 91,4 & 0,0 \\
Kaunotar & 284 & 8,3 & 33,5 & 0,0 \\
Jonsok & 262 & 9,8 & 50,8 & 0,0 \\
Kulkuri & 176 & 11,4 & 18,8 & 0,0 \\
\hline
\end{tabular}

Taulukko 2. Mansikan lajikekokeen satotulokset Rovaniemellä 2009.

\begin{tabular}{llccl}
\hline Lajike & $\begin{array}{l}\text { Kokonaissato } \\
\text { g/taimi }\end{array}$ & $\begin{array}{l}\text { Marjakoko } \\
\text { g/marja }\end{array}$ & $\begin{array}{l}\text { Home } \\
\text { g/taimi }\end{array}$ & $\begin{array}{l}\text { Härmä } \\
\text { g/taimi }\end{array}$ \\
\hline Polka & 222 & 8,8 & 18,2 & 0,0 \\
Honeoye & 157 & 11,8 & 8,6 & 0,0 \\
Korona & 184 & 7,6 & 10,9 & 0,0 \\
Bounty & 229 & 9,0 & 9,6 & 0,0 \\
Suvetar & 120 & 10,9 & 7,9 & 0,0 \\
Valotar & 131 & 7,8 & 3,1 & 0,0 \\
Senga Seng. & 235 & 8,4 & 21,9 & 0,0 \\
Kaunotar & 126 & 7,3 & 5,9 & 0,0 \\
Jonsok & 67 & 6,6 & 11,1 & 0,0 \\
Kulkuri & 32 & 10,4 & 0,5 & 0,0 \\
\hline
\end{tabular}




\section{Johtopäätökset}

Sotkamossa satoisiksi osoittautuivat lajikkeet Polka, Honeoye, Korona ja Bounty. Rovaniemellä selvästi parasta lajiketta ei kokeissa noussut esiin, mutta kokonaissadoltaan suurimmiksi ylsivät vanhat lajikkeet Senga Sengana, Bounty ja Polka. Uusimpien lajikkeiden Suvetar ja Valotar satomäärät riittivät Sotkamossa kannattavaan viljelyyn, vaikka ne eivät yltäneetkään parhaimpien lajikkeiden satotasolle. Kaunotar -lajikkeen sato Sotkamossa oli keskimääräistä pienempi. Uusien lajikkeiden sadot Rovaniemellä olivat heikot, mutta tasaiset lajikkeiden Suvetar, Valotar ja Kaunotar välillä. Lajike Kulkuri antoi kaikkein heikoimman sadon molemmilla paikkakunnilla.

Harmaahometta esiintyi huomattavasti enemmän Sotkamossa kuin Rovaniemellä. Sotkamon runsaammissa satomäärissä harmaahomeelle herkät lajikkeet erottautuivat selvästi. Senga Sengana, Polka ja Korona osoittautuivat, joko erittäin aroiksi tai keskimääräistä aremmiksi molemmilla paikkakunnilla. Uusista lajikkeista Suvetar oli Sotkamossa erittäin herkkä harmaahomeelle, mutta Rovaniemellä se yllättäen sieti hometta keskimääräistä paremmin. Rovaniemen alhaisemmat sadot ja pienemmät kasvustot ovat saattaneet aiheuttaa pienemmän tautipaineen marjoille ja siten myös helpottaa homeelle arkojen lajikkeiden selviämistä. Kestävyydeltään parhaimmaksi osoittautui lajike Kulkuri. Lajikkeet Valotar, Bounty, Honeoye ja Kaunotar olivat myös keskimääräistä parempia homeenkestävyydeltään molemmilla paikkakunnilla.

Lajikekokeen suurimarjaisimmaksi osoittautui odotetusti lajike Honeoye. Muita lähes samaa kokoluokkaa olevia lajikkeita olivat Kulkuri ja Suvetar. Korona ylsi samaan kokoluokkaan vain Sotkamossa, mutta Rovaniemen oloissa marjakoko jäi selvästi keskimääräistä pienemmäksi.

Yhden vuoden tulosten pohjalta uusista lajikkeista lupaavimmaksi satotasoltaan, homeenkestävyydeltään ja marjakooltaan osoittautui lajike Valotar. Lajike Kulkuri olisi myös kiinnostava erittäin hyvän homeenkestävyytensä ja ison marjakokonsa puolesta, mutta satotasot ovat liian heikot tuottavaan viljelyyn Pohjois-Suomessa. Vanhemmista lajikkeista Bounty osoittautui keskisatoiseksi, homeenkestäväksi ja kokeilemisen arvoiseksi, vaikka marjakoko jäikin hieman keskimääräistä pienemmäksi. Lajikekokeen jatko näyttää, pystyvätkö lajikkeet Valotar ja Bounty sopeutumaan pohjoisen oloihin pidemmällä aikavälillä ja tuottamaan riittävästi hyvänlaatuista satoa.

\section{Kirjallisuus}

Hietaranta, T. 2007. Mansikkauutuudet: Kaunotar-varhaislajike ja Kulkuri-koejaloste. Teoksessa: Saila Karhu (toim. ed.). Sadonkorjuu - Tutkittua puutarhatuotantoa 2003-2005 Harvest - Horticultural Research Results 2003-2005. MTT:n selvityksiä 139: s. 25-26.

Hietaranta, T. \& Parikka, P. 2008. 'Suvetar' and 'Valotar' - new srawberry cultivars. Agricultural and Food Science 17: 146-152. 